\title{
Use of osmium tetroxide-potassium ferricyanide in reconstructing cells from serial ultrathin sections
}

\author{
Patricia K. Rivlin and Pamela A. Raymond \\ The University of Michigan, Department of Anatomy and Cell Biology, Ann Arbor, MI 48109-0010 (U.S.A.) \\ (Received 29 September 1986) \\ (Revised 2 December 1986) \\ (Accepted 4 December 1986)
}

Key words: Osmium ferricyanide; EM fixation/staining; Serial reconstruction; EM autoradiography; Enhancement of membrane contrast; Extracellular tracer

\begin{abstract}
We describe a technique, modified from Langford and Coggeshall [Anat. Rec., 197 (1980) 297-303; J. Comp. Neurol., 203 (1981) 745-750], for enhancing membrane contrast and defining cellular boundaries, that is useful for reconstructing individual cells from serial ultrathin sections. The cells of interest in our study were neuronal germinal cells and their differentiated progeny in the retinas of young goldfish. These cells were labeled by pulse injections of $\left[{ }^{3} \mathrm{H}\right]$ thymidine, and they were subsequently identified in EM autoradiographs by the presence of silver grains overlying their nuclei. In tissue prepared by traditional procedures (fixation in mixed aldehydes, postfixation in osmium tetroxide) it was difficult to follow the processes of these cells through the complex, dense network of cells in the differentiated retina. However, in tissue postfixed with a mixture of osmium tetroxide and potassium ferricyanide, the contrast of the cell membranes was improved and, in favorable preparations, a dense precipitate was formed in the extracellular spaces, serving to outline individual cells. This greatly faciliated the preparation of reconstructions from serial ultrathin sections.
\end{abstract}

\section{Introduction}

Reconstructing neurons or selected portions of neurons from serial ultrathin sections is always an arduous task, but it is sometimes the only method available to provide answers to specific questions about cellular morphology or synaptic connectivity of individual neurons ("microcircuitry"). The first reconstructions from serial ultrathin sections were accomplished by Sjöstrand (1958) in his investigation of rod photoreceptor terminals in the guinea pig retina. Since then several investigators have worked to develop or improve upon techniques for serial reconstruction (Sjöstrand, 1967; Levinthal and Ware, 1972; Hinds and Hinds, 1974, 1978, 1983; Ware and LoPresti, 1975; Stevens et al., 1980). Much of the recent effort has gone

Correspondence: P.A. Raymond, The University of Michigan, Department of Anatomy and Cell Biology, Ann Arbor, MI 48109-0010, U.S.A. 
into the development of computer-assisted methods, pioneered by Levinthal and colleagues at Columbia University (Levinthal and Ware, 1972; Ware and LoPresti. 1975).

We found that in electron micrographs of postembryonic goldfish retinal tissue fixed conventionally in mixed aldehydes and osmium, fine cellular processes could not be traced through the profuse network of neurons and glia because cellular boundaries lacked sufficient definition. The problem is more acute in differentiated neural tissue than in embryonic material, which has been used for most previous reconstructions (Hinds and Hinds, 1974, 1978. 1983; Shoukimas and Hinds, 1978). In the embryonic nervous system there are large extracellular spaces between cells (Stensaas and Stensaas, 1968: Hattori and Fujita, 1974; Seymour and Berry, 1975), making it easier to recognize and to follow individual cells through several sections. In our study using postembryonic retinal tissue, we attempted to achieve a more optimum preservation of plasma membranes in order to improve the reliability of our reconstructions. We tried several modifications of the fixation protocol, including mixtures of osmium tetroxide-potassium ferrocyanide $\left[\mathrm{OsO}_{4}-\mathrm{K}_{4} \mathrm{Fe}(\mathrm{CN})_{6}\right]$ or osmium tetroxide-potassium ferricyanide $\left[\mathrm{OsO}_{4}-\mathrm{K}_{3} \mathrm{Fe}(\mathrm{CN})_{6}\right]$ or gluteraldehydetannic acid. A buffered mixture of $1 \% \mathrm{OsO}_{4}$ and $1.5 \% \quad \mathrm{~K}_{3} \mathrm{Fe}(\mathrm{CN})_{6}$ used as a postfixation treatment following aldehyde fixation gave the best results, and allowed us to generate reconstructions of (immature) retinal cells that were contained within differentiated neural tissue.

\section{Methods}

\section{Tissue preparation}

Goldfish, sometimes injected intraperitoneally hours or days previously with $\left[{ }^{3} \mathrm{H}\right]$ thymidine, were anesthetized in $0.02 \%$ methane tricaine sulfonate (Sigma), decapitated and the corneas punctured. The heads were placed in an ice-cold mixture of $3 \%$ gluteraldehyde (Tousimis), 3\% paraformaldehyde, $0.1 \%$ picric acid, 1 $\mathrm{mM} \mathrm{CaCl}_{2}$, and $5 \%$ sucrose in either $0.1 \mathrm{M}$ phosphate buffer, $\mathrm{pH} 7.4$ or $0.1 \mathrm{M}$ cacodylate buffer, pH 7.4 (modified from Langsford and Coggeshall, 1980). After 1 $\mathrm{h}$, the head was bisected (with small fish, about $1 \mathrm{~cm}$ or less in length and less than 60 days old) or the eyes were removed (with larger, older animals). The lens was removed from the enucleated eyes, and the tissues were placed in the same fixative at $4^{\circ} \mathrm{C}$ overnight. After rinsing 3 times for $10 \mathrm{~min}$ each in the same buffer with $5 \%$ sucrose at room temperature (RT), the eyes were trimmed into wedges; bisected heads from small fish were left intact. Blocks were then placed in one of the following solutions in the same buffer, but without sucrose:

(1) $1 \% \mathrm{OsO}_{4} / 1.5 \% \mathrm{~K}_{3} \mathrm{Fe}(\mathrm{CN})_{6}, 2 \mathrm{~h}$ or $4 \mathrm{~h}$ at RT.

(2) $1 \% \mathrm{OsO}_{4} / 0.8 \% \mathrm{~K}_{3} \mathrm{Fe}(\mathrm{CN})_{6}, 2 \mathrm{~h}$ at RT.

(3) $2 \% \mathrm{OsO}_{4} / 0.8 \% \mathrm{~K}_{3} \mathrm{Fe}(\mathrm{CN})_{6}, 2 \mathrm{~h}$ at RT.

(4) $1 \% \mathrm{OsO}_{4} / 0.8 \% \mathrm{~K}_{4} \mathrm{Fe}(\mathrm{CN})_{6}, 2 \mathrm{~h}$ at RT.

(5) $0.6 \% \mathrm{OsO}_{4} / 0.4 \% \mathrm{~K}_{4} \mathrm{Fe}(\mathrm{CN})_{6}, 2 \mathrm{~h}$ at RT.

(6) $1 \% \mathrm{OsO}_{4}, 2 \mathrm{~h}$ at RT. 
With another series of fish, the bisected heads or eyes were fixed in $1 \%$ tannic acid and 3\% gluteraldehyde (Mizuhira and Futaesuku, 1971) in 0.1 M cacodylate buffer, $\mathrm{pH} 7.4$, overnight at $4^{\circ} \mathrm{C}$. Following rinsing and further dissection as above, blocks were postfixed for $2 \mathrm{~h}$ at $\mathrm{RT}$ in one of the following solutions in the same buffer: (1) $1 \% \mathrm{OsO}_{4} / 1.5 \% \mathrm{~K}_{3} \mathrm{Fe}(\mathrm{CN})_{6}$ or (2) $1 \% \mathrm{OsO}_{4}$.

Blocks were rinsed and sometimes stained in uranyl acetate (Coggeshall and Langford, 1981), then dehydrated in graded ethanols and embedded in Spurr (Polysciences).

\section{Serial sectioning}

The consistent retrieval of serial sections is crucial to the reconstruction process. It is therefore essential to cut ribbons of attached sections, and to aid in the formation of ribbons the leading and trailing surfaces of the block face were coated with Weldwood cement (Farenbach, 1984). Short ribbons were picked up on slot grids coated with $0.5 \%$ formvar (Tousimis). We found that carbon coating, which is often used to stabilize formvar films under the electron beam, caused the film to become brittle, which increased the loss of sections during subsequent handling (Farenbach, 1984). At intervals of every 25 th section a short ribbon of 2-3 sections was reserved for autoradiography. Usually no more than 50 sections were cut before the microtome was stopped and sections were collected. The block was then retracted slightly and sectioning was resumed. All sections were cut on a ReichertJung Ultracut E ultramicrotome.

\section{Autoradiography}

Sections designated for autoradiography were processed with a flat substrate method (Salpeter and Bachmann, 1964; Davis et at., 1979), modified as described previously (Raymond and Rivlin, 1987).

\section{Serial reconstruction}

About 150-200 sections were needed to reconstruct an entire germinal cell in the retina. Cells with $\left[{ }^{3} \mathrm{H}\right]$ thymidine labeling over their nuclei were selected from autoradiographs near the middle of the serial set. Photographic negatives were prepared from every third to fifth section at a magnification of 3500-6000x. Typically 6-8 overlapping micrographs were needed for each cell or cluster of cells on each section. Montages were prepared from prints at a final magnification of $8900 \times$ to $15000 \times$.

The outer boundaries of selected cells and their nuclei were traced onto acetate sheets and successive transparencies were aligned according to the method described by Stevens et al. (1980). For the subsequent stages in the reconstruction we used a simple, inexpensive computer graphics package called PLOTTER (J. Kilgore, P. Raymond, T. Connelly and F. Bookstein, copyright, 1984, proprietary software of the University of Michigan). The cellular profiles were digitized with a Summagraphics tablet linked to a Tektronix 4054 or an IBM AT, and 3-dimensional reconstructions were generated by the PLOTTER program, using the University of Michigan mainframe computer (Amdahl 5860) or an IBM AT. 


\section{Results}

Solutions of ferrocyanide and osmium contained a brownish precipitate whereas ferricyanide and osmium gave a clear amber-colored fluid. All combinations of osmium tetroxide with potassium ferrocyanide/ferricyanide yielded enhanced stain-

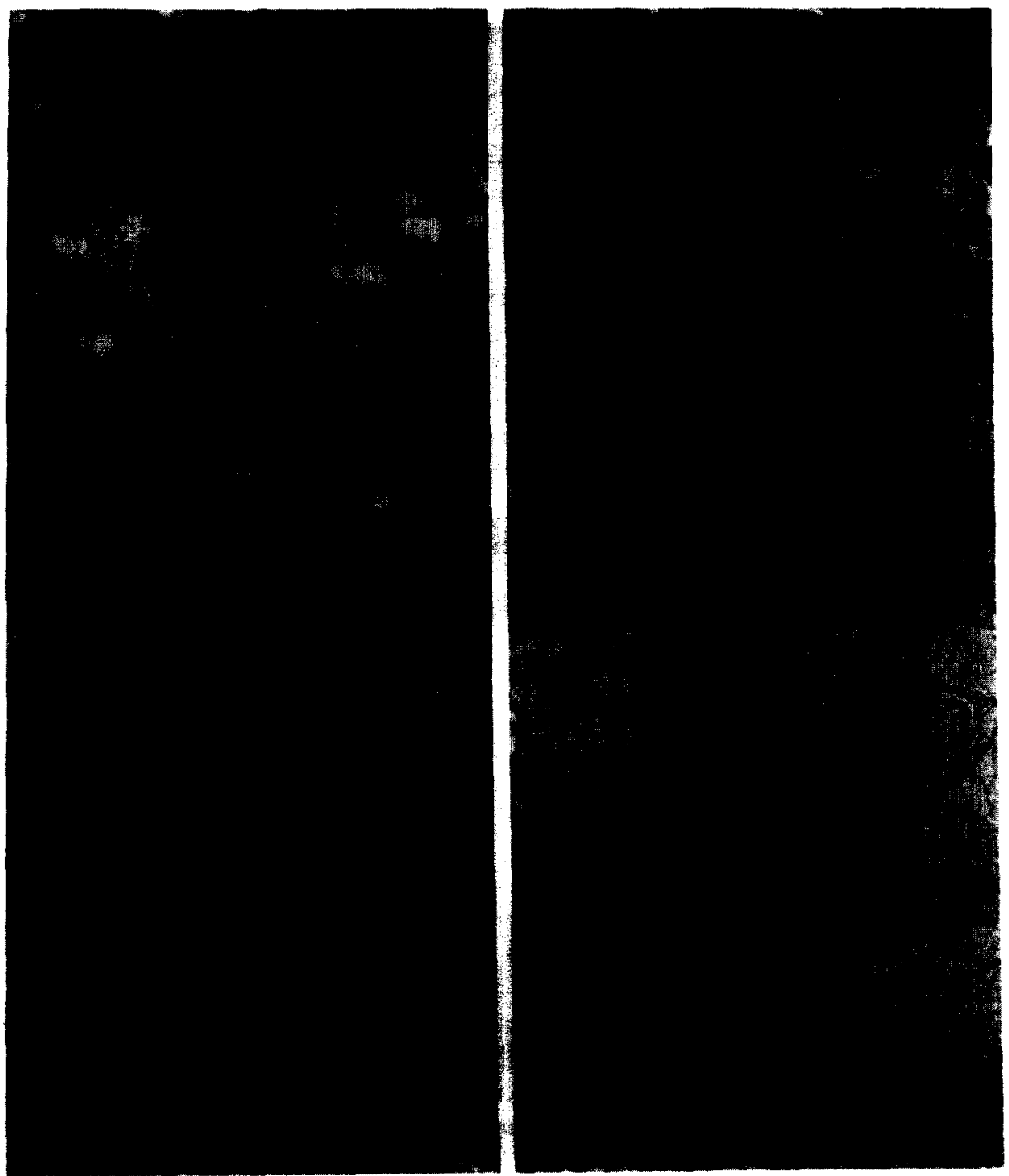

Fig. 1. Electron micrographs of comparable regions of retina from two larval goldfish. The two retinas were processed identically except that A was treated with $1 \%$ osmium tetroxide and B with $1 \%$ osmium tetroxide/1.5\% potassium ferricyanide. PR, photoreceptors; ONL, outer nuclear layer: INL, inner nuclear layers; M. Müller glial cells. The calibration bar is $10 \mu \mathrm{m}$ and applies to both $\mathrm{A}$ and $\mathrm{B}$. 
ing of the plasma membrane compared to osmium tetroxide used alone (Fig. 1). Langford and Coggeshall (1980) reported that in mammalian neural tissue treated with osmium solutions containing potassium ferrocyanide (Karnovsky, 1971) preservation of cytoplasm was less than optimal and nuclei were extracted. We did not observe this in teleost retina. We selected $1 \%$ osmium tetroxide $\left(\mathrm{OsO}_{4}\right) / 1.5 \%$ potassium ferricyanide $\left[\mathrm{K}_{3} \mathrm{Fe}(\mathrm{CN})_{6}\right]$ as our standard mixture, although other combinations seemed to work equally well. This is the same solution chosen by Langford and Coggeshall (1980) to optimally preserve myelin in central and peripheral nerves. We tried both $2 \mathrm{~h}$ and $4 \mathrm{~h}$ incubations, again with equally good results. Coggeshall and Langford $(1980,1981)$ used cacodylate buffer, but we preferred phosphate buffer because it resulted in better preservation of photoreceptor outer segments, and extracellular spaces were filled with an electron dense product (Fig. 1). Tissues fixed with tannic acid and glutaraldehyde were not
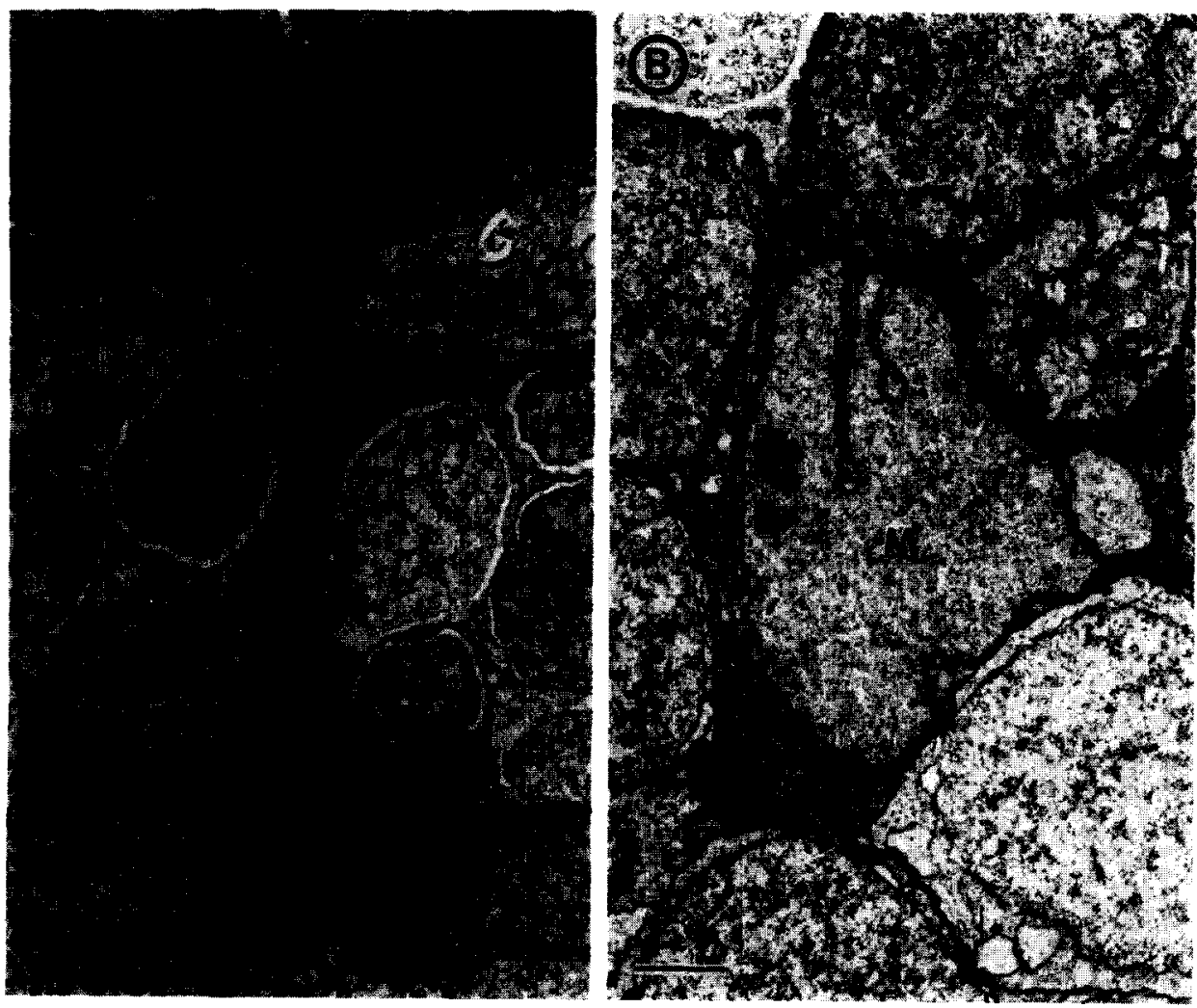

Fig. 2. Electron micrographs showing selective staining of Müller cells with osmium-ferricyanide. A: in some regions, the cytoplasm of Müller cells $(\mathrm{M})$ is filled with an electron-opaque product; mitochondria (arrowheads) are not heavily stained. Calibration bar is $5 \mu \mathrm{m}$. B: where the opaque intracellular precipitate is absent, the selective staining of glycogen (arrowheads) is observed in Müller cells (M). Calibration bar is $1 \mu \mathrm{m}$. 


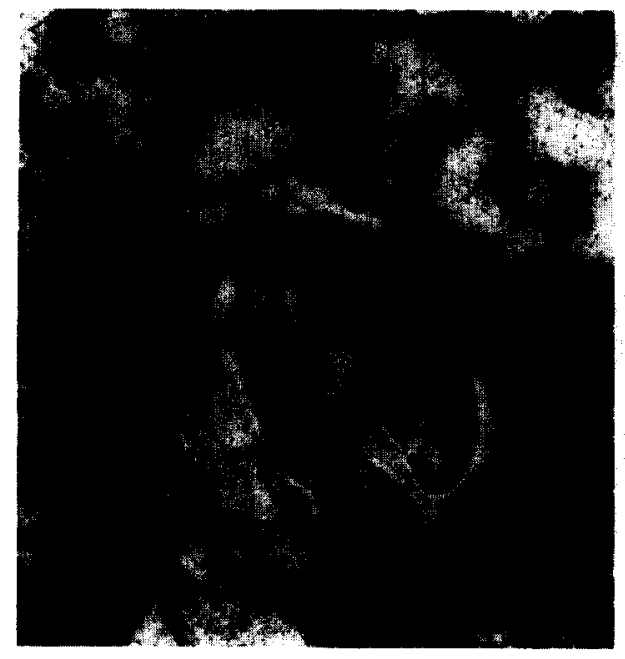

C

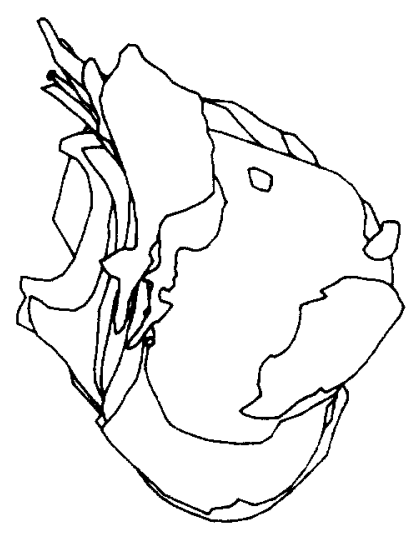

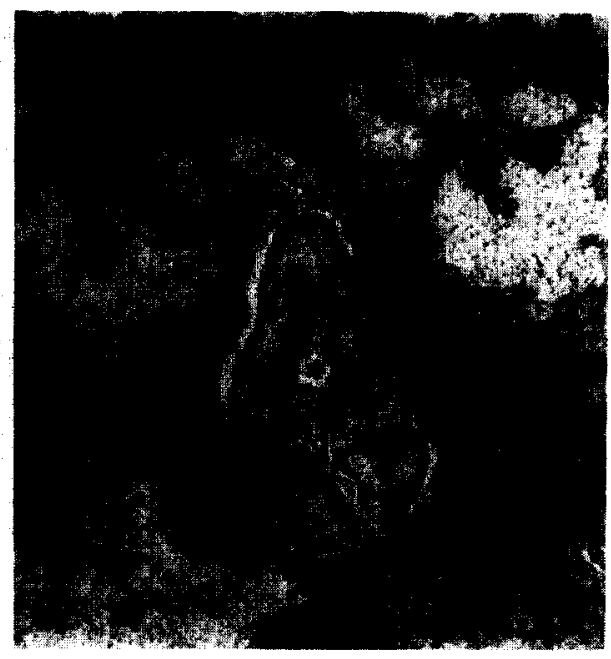

D

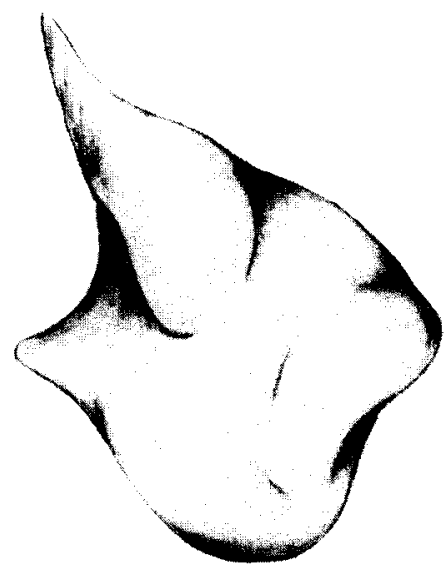

Fig. 3. A: EM autoradiograph of a germinal cell labeled by $\left[{ }^{3} \mathrm{H}\right]$ thymidine injected into a larval goldfish $12 \mathrm{~h}$ prior to fixation of the tissue for histological processing. B: electron micrograph of another section in the serial set which was not processed for autoradiography. The cell labeled in $\mathrm{A}$ is indicated by *. $\mathrm{C}$ : computer-generated serial reconstruction of the labeled cell. D: artist's drawing of the cell. Calibration bar is $1 \mu \mathrm{m}$ and applies to A-D.

Fig. 4. Serial reconstructions from EM autoradiographs. A: a cluster of germinal cells labeled by $\left.\overrightarrow{[}{ }^{3} \mathrm{H}\right]$ thymidine injected into a larval goldfish $12 \mathrm{~h}$ prior to fixation of the tissue for histological processing. Not all of the cells in the cluster have incorporated the label; the ones which have were in the S-phase of the mitotic cycle (during which DNA is synthesized) while the radionucleotide was available. Reconstructions of cell 1 (labeled with $\left[{ }^{3} \mathrm{H}\right]$ thymidine) are shown in $B$ and $C$ and of cell 2 (not labeled) are shown in $\mathrm{D}$ and $\mathrm{E}$. Calibration bar in $\mathrm{A}$ is $2 \mu \mathrm{m}$; calibration bar in $\mathrm{B}$ is $1 \mu \mathrm{m}$ and also applies to $\mathrm{C}-\mathrm{E}$. 

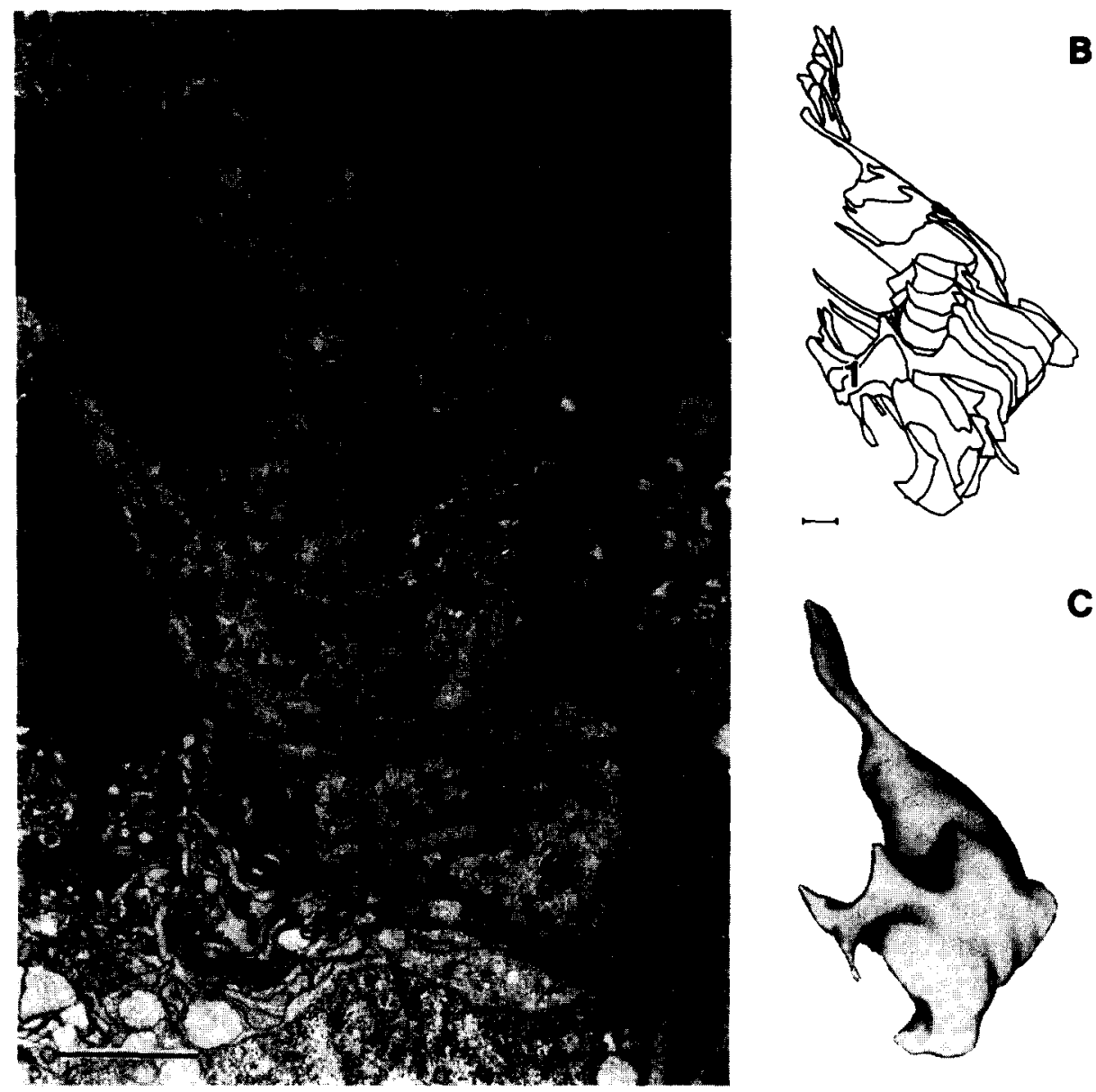

B

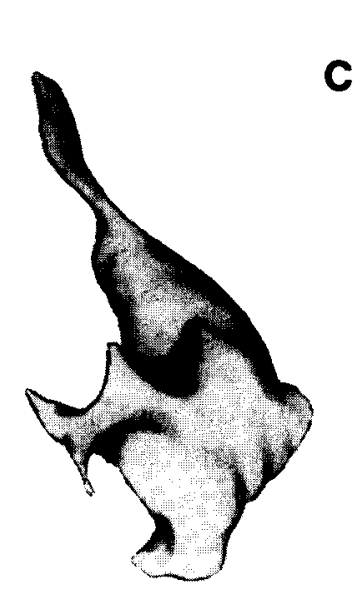

E
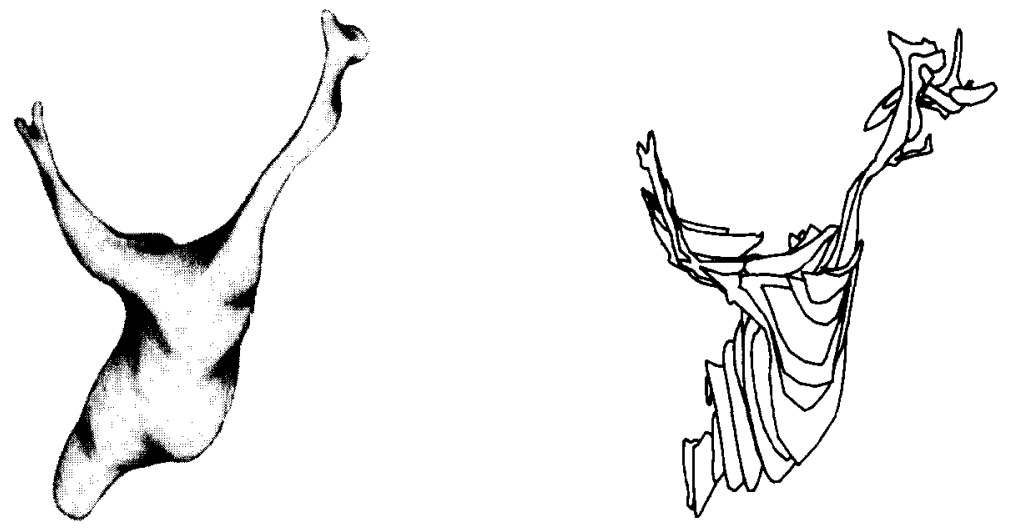
improved for purposes of reconstruction over those fixed with a mixture of picric acid, glutaraldehyde and paraformaldehyde, as recommended by Langford and Coggeshall (1980).

The major disadvantage of the osmium-ferricyanide method was that the enhanced staining of membranes and the presence of extracellular precipitate was sometimes capricious. In many of the blocks we examined, certain regions were well infiltrated with the stain whereas others were not. This variable filling of extracellular space and uneven staining of membranes has been reported in many previous studies using osmium-ferricyanide/ferrocyanide (Forbes et al., 1977; Hepler, 1981; Schnepf et al., 1982). In our preparations, the problem was most apparent in the young eyes, fixed in situ within the head (but with the corneas punctured). The larger eyes, which were cut into smaller pieces before being placed in osmium-ferricyanide, were in general better stained. We suspect that the cause of the poor staining was failure of the solution to penetrate completely and evenly in the tissue block, as suggested by Hepler (1981).

In addition to the enhanced definition of cell membranes and extracellular spaces, in retinas treated with ferricyanide the reconstruction of neural cells was made easier by the improved contrast between neuronal and Müller glial cell cytoplasm. Müller cells were more electron dense than surrounding neurons, and in some regions fine Müller cell processes were completely filled with a dense precipitate (Fig. 2A). Elsewhere, the Müller cytoplasm was dense but not opaque, and glycogen granules, typically found in abundance in Müller cells (Rasmussen, 1972). were selectively stained (Fig. 2B). De Bruijn and Den Breejen (1975) have previously described selective staining of glycogen by osmium-ferricyanide mixtures. We found that the contrast of glycogen was enhanced even in tissue treated en bloc with uranyl acetate, a procedure that is generally believed to extract much of the glycogen (Vye and Fischman, 1970). Because retinal neurons and neuronal germinal cells do not usually contain glycogen (Peters et al., 1976; Hinds and Hinds, 1974, 1978), the distinction between glial and neuronal processes was readily apparent in this material.

Figs. 3 and 4 give some examples of germinal cells reconstructed from goldfish retinas treated with osmium-ferricyanide. The germinal cells are labeled with $\left[{ }^{3} \mathrm{H}\right]$ thymidine in EM autoradiographs (Figs. 3A, 4A). Serial reconstructions of selected labeled cells (Figs. 3C, 3D, 4B-E) show a diverse morphology, but all cells have one (sometimes two) apically directed process. The shapes of these cells are relatively simple, compared with the differentiated retinal neurons reconstructed by Sterling and colleagues from mature cat retina (Stevens et al., 1980; Sterling, 1983; McGuire et al., 1984). They more closely resemble the germinal cells and immature neurons shown by Hinds and Hinds in early embryonic mouse retina (1974, 1978).

\section{Discussion}

Karnovsky (1971) first suggested the use of ferrocyanide-reduced osmium tetroxide to improve membrane contrast in tissues that were poorly preserved by aldehyde 
fixation. Various modifications of Karnovsky's original protocol $(0.6 \%$ osmium tetroxide $/ 0.4 \%$ potassium ferrocyanide) have been developed, using either ferrocyanide or ferricyanide ions. Some workers have reported the use of these preparations in cytochemical studies, to selectively stain various cellular organelles (glycogen; De Bruijn and Den Breejen, 1975; sarcotubular systems in muscle: Forbes et al., 1977; rough endoplasmic reticulum and nuclear envelope: Hepler, 1981; smooth endoplasmic reticulum: Walz, 1982). As a cytochemical stain, osmium-ferrocyanide/ferricyanide is not ideal, however, as it has given variable and sometimes contradictory results with different cell types (Schnepf et al., 1982). The presence of $\mathrm{Ca}^{2+}$ appears to play some role in determining which membrane systems are selectively stained, since removal of $\mathrm{Ca}^{2+}$ from the primary (aldehyde) fixation, or addition of $\mathrm{PO}_{4}^{2-}$ (which precipitates $\mathrm{Ca}^{2+}$ ) abolishes the selective staining of endoplasmic reticulum and nuclear envelope in plant cells (Hepler, 1981) and of sarcoplasmic reticulum in vertebrate muscle cells (Forbes et al., 1977) and of smooth endoplasmic reticulum in leech photoreceptor cells (Walz, 1982).

The use of osmium-ferrocyanide as an extracellular tracer has been reported previously (Forbes et al., 1977; Aguas, 1982). In muscle, freshly prepared solutions of osmium-ferrocyanide produce optimum filling of extracellular spaces when phosphate buffer is used and $\mathrm{Ca}^{2+}$ is omitted from the aldehyde fixation (Forbes et al., 1977). (The opposite condition, presence of $\mathrm{Ca}^{2+}$ and omission of $\mathrm{PO}_{4}^{2-}$ produced selective staining of intracellular tubular membrane systems, Forbes et al., 1977.) Aguas (1982) found that solutions of osmium tetroxide-potassium ferrocyanide stored for 3 months or longer produced consistent filling of extracellular space with electron-opaque deposits, but no staining of intracellular membrane compartments in rat liver cells. He suggested that the progressive reduction of osmium by ferrocyanide during the long period of storage yields large aggregates that are unable to penetrate cell membranes (Aguas, 1982). For serial reconstructions, it is the presence of this opaque precipitate filling the spaces between cells that provides the key to its usefulness.

The mechanisms of staining by osmium-ferricyanide/ferrocyanide mixtures are not completely understood, but they are certainly complex. It is clear that both osmium and iron compounds must be present simultaneously to produce the enhanced contrast, which indicates that the intermediate compound(s) formed by the reactants is/are required (White et al., 1979).

The use of osmium-ferricyanide to improve the ultrastructural appearance of neural tissues, specifically myelinated nerve fibers, has already been shown by Langford and Coggeshall $(1980,1981)$. They did not describe enhanced staining of glycogen, although they did report that the cytoplasm of Schwann cells was more electron dense than in preparations fixed conventionally in $\mathrm{OsO}_{4}$ alone (Langford and Coggeshall, 1981). They also did not observe extracellular deposition of electron-opaque deposits, but this may have been due to their consistent use of $\mathrm{Ca}^{2+}$ in combination with cacodylate buffer in the aldehyde fixative, a situation that is unfavorable for extracellular staining (Forbes et al., 1977).

The usefulness of osmium-ferricyanide for serial reconstruction of neural cells is not limited to retinal tissue; a slightly modified procedure has produced excellent 
results with vestibular neurons in rats (M.D. Ross, personal communication). It may be that the procedure will require slight modifications, of reagent concentrations or incubation times, for optimum staining in different types of neuronal tissues. However, we believe that more widespread use of osmium-ferricyanide will make serial reconstructions easier and faster independent of the kinds of cells to be reconstructed or the methods of reconstruction to be used. Finally, another nice feature of the enhanced contrast provided by the osmium-ferricyanide treatment is that electron micrographs retain good contrast and resolution suitable for publication even at low magnifications (Fig. 1 is at $3400 \times$ ).

\section{Acknowledgements}

This work was supported by NIH grant EY04318 and a Sloan Research Fellowship from the Alfred P. Sloan Foundation to P.A.R. Ms. Sharon Moskwiak typed the manuscript.

\section{References}

Aguas, A.P. (1982) The use of osmium tetroxide-potassium ferrocyanide as an extracellular tracer in electron microscopy, Stain Technol., 57: 69-73.

Davis, T.L., Spencer, R.F. and Sterling, P. (1979) Preparing autoradiograms of serial sections for electron microscopy, J. Neurosci. Meth., 1: 179-188.

De Bruijn, W.C. and Den Breejen, P. (1975) Glycogen, its chemistry and morphological appearance in the electron microscope. II. The complex formed in the selective contrast staining of glycogen, Histochem. J., 7: 205-229.

Fahrenbach, W.H. (1984) Continuous serial thin sectioning for electron microscopy, J. Electron. Microse. Tech., 1: 387-398.

Forbes, M.S., Plantholt, B.A. and Sperelakis, N. (1977) Cytochemical staining procedures selective for sarcotubular systems of muscle: modifications and applications, J. Ultrastruc. Res., 60: 306-327.

Hattori, T. and Fujita, S. (1974) Scanning electron microscopic studies on morphology of matrix cells, and on development and migration of neuroblasts in human and chick embryos, J. Electron Microsc., 23: $269-276$.

Hepler, P.K. (1981) The structure of the endoplasmic reticulum revealed by osmium tetroxide-potassium ferricyanide staining, Eur. J. Cell Biol., 26: 102-110.

Hinds, J.W. and Hinds, P.L. (1974) Early ganglion cell differentiation in the mouse retina: an electron microscopic analysis utilizing serial sections, Dev. Biol., 37: 381-416.

Hinds, J.W. and Hinds, P.L. (1978) Early development of amacrine cells in the mouse retina: an electron microscopic, serial section analysis, J. Comp. Neurol., 179: 277-300.

Hinds, J.W. and Hinds, P.L. (1983). Development of retinal amacrine cells in the mouse embryo: evidence for two modes of formation, J. Comp. Neurol., 213; 1-23.

Karnovsky, M.J. (1971) Use of ferrocyanide-reduced osmium tetroxide in electron microscopy. In: Abstracts of the American Society for Cell Biology, New Orleans, p. 146.

Langford, L.A. and Coggeshall, R.E. (1980) The use of potassium ferricyanide in neural fixation, Anat. Rec. 197: 297-303.

Langford, L.A. and Coggeshall, R.E. (1981) Branching of sensory axons in the peripheral nerve of the rat, J. Comp. Neurol., 203: 745-750.

Levinthal, C. and Ware, R. (1972) Three-dimensional reconstruction from serial sections, Nature (London), 236: 207-210. 
McGuire, B.A., Stevens, J.K. and Sterling, P. (1984) Microcircuitry of bipolar cells in cat regina, J. Neurosci., 4: 2920-2938.

Mizuhira, V. and Futaesaku, Y. (1971) On the new approach of tannic acid and digitonine to the biological fixatives, Proc. Electron Microsc. Soc. Am., 29: 494.

Peters, A., Palay, S.L. and Webster, H.deF. (1976) The Fine Structure of the Nervous System. The Neurons and Supporting Cells, W.B. Saunders, Philadelphia, 406 pp.

Rasmussen, K.E. (1972) A morphometric study of the Müller cell cytoplasm in the rat retina, J. Ultrastruc. Res., 39: 413-429.

Raymond, P.A. and Rivlin, P.K. (1987) Germinal cells in the goldfish retina that produce rod photoreceptors, Dev. Biol., in press.

Salpeter, M.M. and Bachman, L. (1964) Autoradiography with the electron microscope, a procedure for improving resolution, sensitivity and contrast, J. Cell Biol., 22: 469-477.

Schnepf, E., Hausmann, K. and Herth, W. (1982) The osmium tetroxide-potassium ferrocyanide ( $\mathrm{OsFeCN}$ ) staining technique for electron microscopy: a critical evaluation using ciliates, algae, mosses, and higher plants, Histochemistry, 76: 261-271.

Seymour, R.M. and Berry, M. (1975) Scanning and transmission electron microscopic studies of interkinetic nuclear migration in the cerebral vesicles of the rat, J. Comp. Neurol., 260: 105-126.

Shoukimas, G.M. and Hinds, J.W. (1978) The development of the cerebral cortex in the embryonic mouse: an electron microscopic serial section analysis, J. Comp. Neurol., 179: 795-830.

Sjöstrand, F.S. (1958) Ultrastructure of retinal rod synapses of the guinea pig eye as revealed by three-dimensional reconstruction from serial sections, J. Ultrastruc. Res., 2: 122-170.

Sjöstrand, F.S. (1967) Electron Microscopy of Cells and Tissue, Academic Press, New York, 462 pp.

Stensaas, L.J. and Stensaas, S.S. (1968) An electron microscopic study of cells in the matrix and intermediate laminae of the cerebral hemisphere of the $15 \mathrm{~mm}$ rabbit embryo, Z. Zellforsch., 91: $341-365$.

Sterling, P. (1983) Microcircuitry of the cat retina, Annu. Rev. Neurosci., 6: 149-185.

Stevens, J.K., Davis, T.L., Friedman, N. and Sterling, P. (1980) A systematic approach to reconstructing microcircuitry by electron microscopy of serial sections, Brain. Res. Rev., 2: 265-293.

Vye, M.V. and Fischman, D.A. (1970) The morphological alteration of particulate glycogen by en bloc staining with uranyl acetate, J. Ultrastruc. Res., 33: 278-291.

Walz, B. (1982) $\mathrm{Ca}^{2+}$-Sequestering smooth endoplasmic reticulum in an invertebrate photoreceptor. I. Intracellular topography as revealed by $\mathrm{OsFeCN}$ staining and in situ $\mathrm{Ca}$ accumulation, J. Cell Biol., 93: 839-848.

Ware, R.W. and LoPresti, V. (1975) Three-dimensional reconstruction from serial sections, Int. Rev. Cytol., 40: 325-440.

White, D.L., Mazurkiewicz, J.E. and Barnett, R.J. (1979) A chemical mechanism for tissue staining by osmium tetroxide-ferrocyanide mixtures, J. Histochem. Cytochem., 27: 1084-1091. 